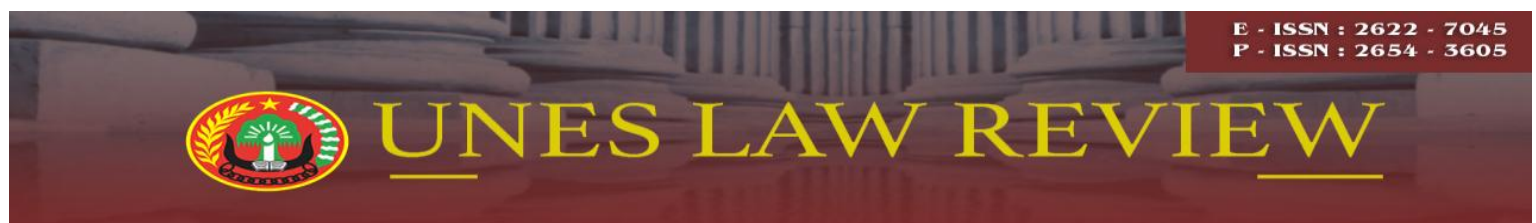

Email : uneslawreview@gmail.com Online : http://review-unes.com/index.php/law/index

Volume 1, Issue 4, Juni 2019

E-ISSN : 2622-7045

P-ISSN : 2654-3605

\title{
PERLINDUNGAN HUKUM TERHADAP PETUGAS LEMBAGA PEMASYARAKATAN DALAM PELAKSANAAN TUGAS PENGAMANAN PADA LAPAS KLAS IIA PADANG
}

\author{
Ernawati \\ Program Magister Ilmu Hukum, Universitas Ekasakti \\ Email : zonaq2014@gmail.com
}

\begin{abstract}
Legal protection against Correctional Officers in carrying out security duties is based on Law No. 12 of 1995 concerning Correctional Services. Given the risks posed by security duties at Correctional Institutions, the Security Officers need to be given legal protection so that the aims and objectives of implementing security tasks can be achieved. which in turn the correctional goals themselves can be realized. With such a background, there are two main problems in implementing legal protection against correctional officers, namely: First What is the legal protection of Correctional Officers in the implementation of security duties at the Padang Class IIA Correctional Institution? Second What are the Constraints of Constraints encountered in the Implementation of Legal Protection for Correctional Officers in the Implementation of the Duty of Security at the Padang Class IIA Correctional Institution? The implementation of legal protection in terms of answering the existing problems, which is seen in the implementation in Padang Class IIA Lapas can be understood that the legal protection of correctional officers in Lapas Klas IIA Padang is carried out based on legal provisions regarding correctional facilities. In this case Padang Class IIA Lapas provides legal protection to correctional officers in carrying out security duties carried out in accordance with applicable legal rules concerning correctional duties and legal rules regarding security itself. The rule of implementative law regarding correcting about safeguards refers to legal rules regarding correctional codes of ethics and legal rules concerning the security of prisons regulated in Permenkumham Number M.HH-16.KP.05.02 of 2011 concerning the Code of Conduct for Correctional Staff and Permenkumham No. 33 of 2015 concerning Security at Penitentiary Institutions and State Detention Houses. The implementation of legal protection against correctional officers in carrying out security duties is carried out based on these legal rules, so that legal protection for correctional officers can be provided in the event that correctional officers carry out security duties based on applicable legal rules.
\end{abstract}

Kata Kunci : Perlindungan Hukum, Lembaga Pemasyarakatan, Lapas

\section{PENDAHULUAN}

Pengamanan di Lembaga Pemasyarakatan merupakan salah satu bagian penting dalam pelaksanaan pembinaan berdasarkan Sistem Pemasyarakatan yang dianut dalam Undang-Undang Nomor 12 Tahun 1995 tentang Pemasyarakatan. Merujuk pada aturan-aturan yang termaktub dalam Undang-Undang Nomor 12 Tahun 1995 dapat dipahami bahwa pelaksanaan 
pembinaan dan pengamanan harus berjalan secara besinergi untuk tercapainya tujuan pemasyarakatan.

Pentingnya persoalan pengamanan ini diungkapkan secara lebih tegas dalam Peraturan Menteri Hukum dan Hak Asasi Manusia Nomor 33 Tahun 2015 tentang Pengamanan pada Lembaga Pemasyarakatan dan Rumah Tahanan Negara. Pada bagian Menimbang point "a" Peraturan Menteri tersebut diungkapkan bahwa keamanan dan ketertiban yang kondusif di dalam Lembaga Pemasyarakatan dan Rumah Tahanan Negara merupakan syarat utama untuk mendukung terwujudnya keberhasilan pelaksanaan Sistem Pemasyarakatan. Ketentuan dalam Peraturan Menteri itu menjadi dasar utama bahwa persoalan pengamanan tidak bisa diabaikan dalam pelaksanaan pembinaan di Lembaga Pemasyarakatan.

Peraturan Menteri Hukum dan Hak Asasi Manusia RI Nomor 33 Tahun 2015 tentang Pengamanan Lembaga Pemasyarakatan menjadi landasan hukum operasional dalam pelaksanaan pengamanan di Lembaga Pemasyarakatan. Dalam ketentuan tersebut dijabarkan tentang kewenangan dan aspek-aspek pelaksanaan pengamanan oleh Petugas Lembaga Pemasyarakatan.

Pemahamanan tentang pengamanan disebutkan dalam Peraturan Menteri Hukum dan Hak Asasi Manusia RI tersebut pada Pasal 1 yang mengungkapkan bahwa pengamanan adalah segala bentuk tindakan dalam rangka pencegahan, penindakan, penanggulangan dan pemulihan gangguan keamanan dan ketertiban. Dalam Peraturan Menteri Hukum dan HAM tersebut juga diungkapkan pemahamanan tentang Petugas Pemasyarakatan sebagaimana yang terdapat dalam Pasal 1 ayat (5) yang menyebutkan bahwa Petugas Pemasyarakan adalah Pegawai Negeri Sipil yang melaksanakan tugas dibidang pemasyarakatan. Berdasarkan ketentuan dalam Peraturan Menteri Hukum dan Hak Asasi Manusia Nomor 33 Tahun 2015 dapat dipahami bahwa pelaksanaan pengamanan di Lembaga Pemasyarakatan meliputi beberapa tindakan pengamanan .

Uraian lebih lanjut tentang tindakan pengamanan dalam rangka tugas pelaksanaan pengamanan diatur dalam Petunjuk Pelaksanaan (Juklak) dan Petunjuk Teknis (Juknis) tentang pengamanan yang terangkum dalam Standar Operasional dan Prosedural (SOP) serta modul-modul tentang pengamanan.

Teknis pelaksanaan pengamanan di Lembaga Pemasyarakatan dengan merujuk pada aturan tentang Pengamanan Lembaga Pemasyarakatan dan Rumah Tahanan Negara, diuraikan dalam satu Modul tentang Pengamanan di Lembaga Pemasyarakatan dan Rumah Tahanan Negara. Dalam modul tersebut disebutkan bahwa sistem keamanan di Lembaga Pemasyarakatan, Rumah Tahanan Negara, dan Cabang Rumah 
Tahanan Negara pada dasarnya merupakan suatu kegiatan yang dilaksanakan secara terencana, terarah, dan sistematis untuk mewujudkan kehidupan dan penghidupan yang teratur, aman, dan tentram guna menjamin terselenggaranya kegiatan perawatan tahanan, pembinaan Warga Binaan Pemasyarakatan, dan meningkatkan pelayanan masyarakat dalam rangka pencapaian tujuan Pemasyarakatan ${ }^{1}$.

Modul tentang pengamanan tersebut juga menguraikan tentang pentingnya pelaksanaan pengamanan yang memperhatikan aspek-aspek Hak Asasi Manusia. Hal ini memberi arti bahwa pengamanan Lembaga Pemasyarakatan bukan tindakan tanpa batas yang bisa mengarah pada kesewenang-wenangan. Tindakan pengamanan Lembaga Pemasyarakatan adalah tindakan yang berjalan secara beriringan dengan upaya pembinaan yang tujuan utamanya adalah memberikan ketentraman dan kenyamanan bagi Warga Binaan Pemasyarakatan dalam menjalani masa hukuman.

Kehati-hatian tersebut terlihat jelas dalam aturan yang dikeluarkan oleh Kementerian Hukum dan Hak Asasi Manusia yang memberikan batasan-batasan kewenangan terhadap Petugas Pemasyarakatan dalam melaksanakan

1 Samsul Hidayat Modul Pengamanan Pada Lapas dan Rutan, Pusat Pengembangan Teknis dan Kepemimpinan Badan Pengembangan Sumber Daya Manusia Hukum dan HAM, Jakarta. 2017, hlm. 11 -12 pengamanan di Lembaga Pemasyarakatan. Rincian batasan kewenangan tersebut juga diuraikan lebih detail dalam aturan-aturan Petunjuk Pelaksana (Juklak) dan Petunjuk Teknis (Juknis) tentang pengamanan yang dirangkum dalam Standar Operasional dan Prosedural (SOP) dan modul-modul tentang pengamanan.

Merujuk pada ketentuan-ketentuan sebagaimana diamanatkan di atas yang menjelaskan tentang batas kewenangan, teknis pelaksanaan dan prinsip kehati-hatian dalam pelaksanaan tugas pengamanan maka terlihat bahwa pengamanan di Lembaga Pemasyarakatan secara yuridis didasarkan pada ketentuan Undang-undang Nomor 12 Tahun 1995. Penjabaran dari Undang-undang tersebut yang berkaitan dengan pengamanan di Lembaga Pemasyarakatan diatur dalam Peraturan Menteri Hukum dan Hak Asasi Manusia Nomor 33 Tahun 2015. Ketentuan tentang Operasional dan Teknis Pelaksanaan Pengamanan di Lembaga Pemasyarakatan diuraikan lebih lanjut dalam Juklak dan Juknis serta SOP tentang pengamanan di Lembaga Pemasyarakatan. Semua ketentuan tersebut menjadi dasar legalitas pelaksanaan tugas pengamanan oleh Petugas Pemasyarakatan.

Ketentuan-ketentuan tersebut sekaligus menjadi dasar yuridis dalam perlindungan hukum terhadap Petugas pengamanan di Lembaga Pemasyarakatan. Implementasi pelaksanaan tugas pengamanan di Lembaga 
Pemasyarakatan dapat dilihat secara khusus dalam pelaksanaannya di Lembaga Pemasyarakatan Klas IIA Padang.

Pelaksanaan tugas pengamanan di Lembaga Pemasyarakatan Klas IIA Padang memiliki beberapa permasalahan baik itu tentang sumber daya yang ada maupun sarana dan prasarana yang tersedia dalam upaya pelaksanaan tugas pengamanan di Lembaga Pemasyarakatan. Sehubungan dengan hal itu maka penulis dalam penelitian ini tertarik mengambil Judul "Perlindungan Hukum Terhadap Petugas Lembaga Pemasyarakatan Dalam Pelaksanaan Tugas Pengamanan (Studi Pada Lembaga Pemasyarakatan Klas IIA Padang)”.

\section{METODE PENELITIAN}

Penelitian ini merupakan penelitian deskriptif analitis yaitu penelitian yang menggambarkan tentang pelaksanaan Perlindungan hukum terhadap Petugas Lembaga Pemasyarakatan dalam pelaksanaan tugas pengamanan tersebut.

Metode Pendekatan yang digunakan dalam penelitian ini adalah pendekatan Yuridis Normatif sebagai pendekatan utama yang dilakukan dengan cara melihat kenyataan yang ada dalam praktek dilapangan dan didukung dengan pendekatan yuridis empiris dengan cara menelaah teori teori, konsep-konsep, asas- asas hukum serta peraturan perundang-undangan yang berhubungan dengan penelitian ini yakni terkait dengan pelaksanaan perlindungan hukum terhadap petugas Lemaga Pemasyarakatan dalam pelaksanaan tugas pengamanan di Lembaga Pemasyarakatan Klas IIA Padang.

\section{HASIL PENELITIAN DAN ANALISIS}

Bentuk perlindungan hukum petugas Pengamanan di Lembaga Pemasyarakatan Klas IIA Padang

Tugas Pengamanan di Lembaga Pemasyarakatan merupakan salah satu dari tiga lingkup tugas yang ditetapkan oleh Undang-undang Pemasyarakatan terhadap petugas Pemasyarakatan yakni tuga pembinaan, pembimbingan dan pengamanan. Ketiga lingkup tugas tersebut harus berjalan secara bersinergi guna tercapainya tujuan pemasyarakatan yang ditetapkan dalam undang-undang pemasyarakatan.

Ketiga lingkup tugas pemasyarakatan tersebut harus memiliki legitimasi bertindak berdasarkan peraturan hukum yang berlaku termasuk pelaksanaan tugas pengamanan sebagaimana yang telah diuraikan tentang dasar yuridis pelaksanaan tugas pengamanan di Lembaga Pemasyarakatan. Legitimasi hukum tersebut akan memberikan dampak pada aspek yang ditimbulkan dari pelaksanaan tugas pengamanan tersebut yang gilirannya akan berdampak juga terhadap adanya perlindungan hukum terhadap petugas pemasyarakatan dalam menjalankan tugas pengamanan sebagaimana diamanatkan 
dalam aturan-aturan hukum tentang pengamanan di Lembaga Pemasyarakatan.

Dalam praktek penegakan hukum, petugas pemasyarakatan sangat rentan dengan perbuatan yang dipandang menyalahi prosedur yang bukan hanya disebabkan oleh dirinya sendiri tapi juga disebabkan perbuatan dari petugas instansi berwenang lainnya yang memiliki akses langsung terhadap instansi pemasyarakatan ${ }^{2}$. Kerentanan yang dihadapi oleh petugas pemasyarakatan dalam menjalankan tugas pengamanan harus disikapi serius dengan memperhatikan aspek-aspek hukum yang dapat memberi akibat timbulnya kesalahan dalam menjalankan tugas pengamanan oleh petugas pemasyarakatan. Kesalahan demikian itu bisa timbul karena aspek kelalaian petugas bersangkutan, kekeliruan dalam memahami perintah tugas ataupun kesalahan yang ditimbulkan oleh pihak penegak hukum lain yang berdampak lanjutan kepada petugas pemasyarakatan dalam menjalankan tugas pengamanan di Lembaga Pemasyarakatan.

Kerentanan yang dapat menimbulkan kesalahan terhadap petugas pemasyarakatan dalam menjalankan tugas pengamanan sebagai dampak dari perbuatan petugas lainnya yang terjadi di Lembaga Pemasyarakatan Klas IIA Padang adalah

2 Muhari Agus Santoso, Paradigma Baru Hukum Pidana, Averroes Press \& Pustaka Pelajar, Malang, 2004, hlm. 79

tindakan dari Jaksa Penuntut Umum yang dalam dalam melengkapi berkas perkara dari Narapidana seringkali terjadi keterlambatan yang berakibat pada timbulnya tuntutan dari Narapidana yang berimbas pada Petugas Pemasyarakatan dalam menjalankan tugas pengamanan, sebab dalam kasus yang terjadi di Lembaga Pemasyarakatan Klas IIA Padang kesalahan dari Jaksa Penuntut Umum tersebut ditimpakan terhadap petugas pemasyarakatan, hal ini seringkali menimbulkan kesalahpahaman antara narapidana dengan petugas pemasyarakatan ${ }^{3}$.

$$
\text { Kesalahpahaman antara Petugas }
$$

Pemasyarakatan dalam menjalankan tugas pengamanan dengan Narapidana dapat berakibat pada timbulnya kesalahan prosedur dalam menjalankan tugas pengamanan di Lembaga Pemasyarakatan. Hal yang dipandang dapat menyalahi prosedur tersebut mengakibatkan petugas yang melakukannya akan dijatuhi hukuman sesuai peraturan perundang-undangan yang berlaku bila perbuatan yang menyalahi prosedur terjadi akibat perbuatan baik sengaja maupun tidak sengaja yang dilakukan oleh Petugas Pemasyarakatan itu sendiri adalah wajar bila ia sendiri yang harus mempertanggungjawabkannya di hadapan hukum. Namun bila perbuatan menyalahi prosedur tersebut dilakukan Petugas Pemasyarakatan atas perintah instansi penegak hukum yang

${ }^{3}$ Wawancara dengan Ka KPLP Lapas Klas IIA Padang tanggal 06 Maret 2018 
berwenang lainnya, maka adalah tidak adil bila Petugas Pemasyarakatan tersebut yang harus sepenuhnya mempertanggungjawabkan perbuatan tersebut. ${ }^{4}$

Tindakan pengamanan yang memiliki kerentanan terhadap Petugas Pemasyarakatan tersebut diantisipasi oleh Lembaga Pemasyarakatan Klas IIA Padang dengan melakukan koordinasi kerja yang berkelanjutan dengan instansi lainnya guna menghindari segala dampak yang ditimbulkan dari adanya proses hukum yang dijalani oleh narapidana yang berada di bawah kewenangan pihak penegak hukum lainnya. koordinasi tersebut secara intensif dilakukan oleh Lembaga Pemasyarakatan Klas IIA Padang dengan pihak Kepolisian, Kejaksaan dan Pengadilan, sehingga segala sesuatu yang terkait dengan proses hukum yang dijalani oleh narapidana. Koordiansi yang demikin itu dilakukan sebagai dasar pemahaman terhadap tindak pencabutan kemeredekaan yang dilakukan oleh Lembaga Pemasyarakatan merupakan keputusan hukum yang didasarkan pada adanya suratsurat penahanan/keputusan /vonis dari instansi kepolisian, kejaksaan dan pengadilan sebagi surat-surat mutlak yang dapat dijadikan dasar pembenaran secara hukum (justifikasi) bagi pencabutan kemerdekaan seseorang di Rutan/Lapas. Dengan demikian pelaksanaan tugas penegakan hukum tidak

\footnotetext{
${ }^{4}$ Muhari Agus Santoso Op.Cit.
}

hanya terhadap para tahanan yang berada di bawah pengawasannya, tapi juga dalam lingkungan tugasnya (koordinasi) dengan instansi penegak hukum berwenang lainnya.

Bentuk perlindungan hukum lainnya yang ditetapkan terhadap Petugas Pemasyarakatan oleh Lembaga Pemasyarakatan Klas IIA Padang adalah melakukan penekanan pelaksanaan kode etik pemasyarakatan dalam hal hubungan antara Petugas Pemasyarakatan dengan Narapidana. Kode etik bersikap dari Petugas Pemasyarakatan dalam melakukan hubungan dengan Narapidana didasarkan pada ketentuan yang ditetapkan dalam Pasal 7 Permenkumham tentang Kode Etik Pemasyarakatan. Kode Etik bersikap Petugas Pemasyarakatan dengan Narapidana tersebut adalah :

1. Menghormati harkat dan martabat Warga Binaan Pemasyarakatan, meliputi:

a. Menghormati hak Warga Binaan Pemasyarakatan;

b. Menjauhkan diri dari segala bentuk tindak kekerasan dan pelecehan;

c. Menghormati dan menjaga kerahasiaan Warga Binaan Pemasyarakatan; dan

d. Selalu ramah dan sopan dalam berinteraksi dengan Warga Binaan Pemasyarakatan

2. Mengayomi Warga Binaan Pemasyarakatan, meliputi:

a. Memberikan rasa aman dan tentram terhadap Warga Binaan Pemasyarakatan;

b. Menindaklanjuti setiap saran, keluhan, atau pengaduan yang disampaikan 
Warga Binaan Pemasyarakatan secara tepat dan cepat;

c. Tidak diskriminatif terhadap Warga Binaan Pemasyarakatan atas dasar suku, agama, ras atau lainnya yang dapat menimbulkan situasi yang tidak kondusif; dan

d. Memenuhi hak Warga Binaan Pemasyarakatan tanpa mengharapkan balasan/pamrih.

3. Tanggap dalam bertindak, tangguh dalam bekerja dan tanggon dalam kepribadian, meliputi:

a. Teliti, cermat, dan cepat dalam menilai situasi;

b. Mampu mengambil tindakan secara tegas terhadap setiap bentuk perilaku yang melanggar tata tertib/ aturan;

c. Tidak melakukan hal yang bertentangan dengan moral dan hukum;

d. Menguasai keahlian dalam melaksanakan tugas;

e. Kesanggupan untuk menegakkan keadilan dan kejujuran; dan

f. Menjaga kewaspadaan dan kehatihatian.

4. Bijaksana dalam bersikap, meliputi:

a. Menggunakan akal budi, pengalaman, dan pengetahuan secara cermat dan teliti apabila menghadapi kesulitan, tantangan dan hambatan dalam pelaksanaan tugas;

b. Memberikan perhatian khusus terhadap warga binaan pemasyarakatan yang mempunyai kebutuhan khusus, seperti anak-anak, wanita, lanjut usia, atau penderita penyakit permanen;

c. Mempunyai keinginan untuk mengembangkan kapasitas diri untuk mendukung pelaksanaan tugas;

d. Mempunyai kemampuan mengendalikan perkataan, sikap, dan perbuatan sehingga menumbuhkan sikap hormat warga binaan pemasyarakatan; dan e. Mampu menempatkan dirinya secara tepat di hadapan warga binaan pemasyarakatan baik sebagai petugas, teman, saudara, maupun orang tua tanpa kehilangan kewibawaan.

Pelaksanaan sikap etik Petugas Pemasyarakatan tersebut diawasi secara intern di Lembaga Pemasyarakatan Klas IIA Padang. Pengawasan yang dilakukan tersebut sebagai bentuk perlindungan hukum terhadap Petugas Pemasyarakatan khususnya dalam melaksanakan tugas pengamanan agar terhindar dari tindakan-tindakan yang dapat berdampak pelanggaran hukum oleh Petugas Pemasyarakatan. Pengawasan demikian itu dilaksanakan dengan dasar ketentuan Pasal 2 huruf $b$ Permenkumham tentang Pengawasan Intern Pemasyarakatan yang menyebutkan bahwa Pengawasan Intern Pemasyarakatan dilakukan untuk mengurangi segala bentuk penyalahgunaan wewenang, penyimpangan, dan pelanggaran terhadap ketentuan peraturan perundang-undangan.

Ketentuan Peremenkumham tersebut menjadi dasar tentang adanya bentuk perlindungan hukum yang diberikan terhadap petugas pemasyarakatan khususnya dalam hal pelaksanaan tugas pengamanan. perlindungan hukum demikian itu disertai dengan adanya bentuk sanksi yang diberikan kepada petugas pemasyarakatan sebagai bentuk sanksi intern yang didasarkan pada peraturan perundang-undangan yang berlaku bagi petugas pemasyarakatan dalam kapasitasnya sebagai Aparatur Sipil Negara 
(ASN). Hal ini sebagaimana ditetapkan dalam Pasal 19 Permenkumham tentang Pengawasan Intern Pemasyarakatan yang menyebutkan bahwa Pengawas atau Pejabat yang ditunjuk oleh Direktur Jenderal yang melakukan Pengawasan Intern tidak sesuai dengan Peraturan Menteri ini dijatuhi sanksi sesuai dengan ketentuan peraturan perundang-undangan.

Ketentuan pengawasan intern ini dilakukan sebagai bentuk antisipasi terhadap tindak pelanggaran yang berdampak pada pelanggaran hukum pidana yang dilakukan oleh petugas pemasyarakatan. upaya akhir dari perlindungan hukum terhadap petugas pemasyarakatan dalam menjalankan tugas pengamanan adalah memberikan bantuan hukum terhadap petugas pemasyarakatan yang terindikasi tindak pidana. Dasar pemberian bantuan hukum tersebut ditetapkan dalam ketentuan Pasal 36 dan pasal 37 Permenkumham tentang Pengamanan yang menyebutkan bahwa Petugas Pengamanan dalam penyelenggaraan Pengamanan berhak mendapatkan perlindungan sesuai dengan ketentuan peraturan perundang-undangan. Perlindungan hukum bagi Petugas Pengamanan diberikan dalam bentuk bantuan hukum dalam perkara yang dihadapi di pengadilan terkait pelaksanaan tugasnya.
Pelaksanaan Perlindungan Hukum Terhadap Petugas Pemasyarakatan dalam tugas pengamanan di Lapas Klas IIA Padang.

Petugas Pemasyarakatan, berdasarkan ketentuan Pasal 8 UU No 12 tahun 1995 merupakan salah satu aparat penegak hukum selain kepolisian, kejaksaan dan Peradilan. Hal ini memberi arti bahwa petugas pemasyarakatan merupakan bagian integral dari proses penegakan hukum itu sendiri (Integrated Criminal Justice System) yang diawali dari proses penyidikan, penuntutan sampai persidangan yang berakhir dengan vonis pidana yang ujungnya bermuara pada Lembaga Pemasyarakatan sebagai tempat menjalankan pemidanaan. Kedudukan petugas pemasyarakatan sebagai bagian dari aparat penegakan hukum ini belum memiliki eksistensi yang tegas dikalangan masyarakat, yang melihat aparat penegak hukum sebatas polisi, jaksa dan hakim. Sementara petugas pemasyarakatan hanya dipandang sebagai petugas penjaga penjara yang mengedepankan aspek pengamanan tanpa memperhatikan tugas dan fungsi lainnya terutama dalam bidang pembinaan dan pembimbingan. $^{5}$

Petugas Pemasyarakatan sebagai bagian dari petugas penegak hukum harus memiliki kewenangan berupa hak dan tangung jawab dalam menjalankan tugastugas pemasyarakatan. Hak-hak dan

5 satjipto Raharjo, Permasalahan Hukum di Indonesia, Alumni, Bandung, 1983, hlm. 121 
tanggung jawab yang demikian itu harus memiliki implikasi langsung terhadap adanya perlindungan hukum bagi petugas pemasyarakatan dalam menjalankan tugastugas pemasyarakatan baik itu dalam bidang pembinaan, pembimbingan maupun pengamanan. Hal inilah yang akan memberikan rasa aman dan adanya jaminan terlaksananya hak-hak petugas pemayarakatan dalam menjalankan tugastugas pemasyarakatan. ${ }^{6}$

Perlindungan hukum terhadap petugas pemasyarakatan dapat diberikan dalam hal tugas pemasyarakatan yang dijalankan sesuai dengan aturan yang berlaku dan Protap pelaksanaan tugas pemasyarakatan yang telah ditetapkan untuk dijalankan di Lembaga Pemasyarakatan. Kesalahan yang dapat timbul dalam pelaksanaan tugas yang demikian itu bersifat kondisonal dalam hal adanya hal-hal yang tidak dapat diprediksi dalam menghadapi kejadian di lapangan. Keadaan yang demikian itu jika dianalogikan pada tugas kepolisian dapat ditemukan pada adanya kewenangan deskresi yang dimiliki oleh kepolisian dalam menghadapi keadaan yang tidak dapat diprediksi ketika menjalankan tugas di lapangan. Kewenangan yang seperti ini tidak dimiliki oleh petugas pemasyarakatan, walaupun dalam

${ }^{6}$ Didin Sudirman, Reposisi dan Revitalisasi Pemasyarakatan dalam Sistem Peradilan Pidana di Indonesia, Pusat Pengkajian dan Pengembangan Kebijakan Departemen Hukum dan Hak Asasi Manusia RI, Jakarta, 2007, hlm. 10 pelaksanaan tugas pemasyarakatan kondisi yang tidak terprediksi itu dapat terjadi khusunya dalam pelaksanaan tugas pengamanan di Lembaga Pemasyarakatan.

Merujuk hal yang demikian itu maka perlindungan hukum terhadap petugas pemasyarakatan dalam menjalankan tugas pengamanan harus mendapat perhatian khusus guna memberikan kenyamanan dan menjamin terlaksananya hak-hak petugas pemasyarakatan dalam menjalankan tugas pengamanan di Lembaga Pemasyarakatan. Pandangan yang demikian inilah yang menjadi salah satu point bagi bagi Lembaga Pemasyarakatan Klas IIA Padang dalam memperhatikan berbagai aspek yang terkait dalam upaya perlindungan hukum terhadap petugas pemasyarakatan terutama bagi petugas yang bertanggung jawab terhadap persoalan keamanan di Lembaga Pemasyarakatan Klas IIA Padang. Hal ini sebagaimana diungkapkan langsung oleh Kepala Lapas Klas IIA Padang yang menyampaikan bahwa Petugas pengamanan di Lembaga pemasyarakatan harus sangat diperhatikan aspek perlindungan hukumnya, sebab bukan tidak mungkin petugas pengamanan di Lembaga Pemasyarakatan akan terdorong untuk melakukan tindakan yang bersinggungan dengan hukum akibat tekanan keadaan dalam menjalankan tugas pengamanan. $^{7}$

\footnotetext{
${ }^{7}$ Ibid
} 
Menyikapi kondisi riskan dari petugas pengamanan ini, maka sangat penting adanya pemahamanan dari petugas pemasyarakatan di Lapas Klas IIA Padang mengenai berbagai aturan dalam pelaksanaan tugas pengamanan. Hal ini menjadi penekanan penting yang diungkapkan oleh Kepala Lapas Klas IIA Padang terhadap semua petugas pengamanan di Lembaga Pemasyarakatan Klas IIA Padang, sebab pelaksanaan tugas yang sesuai dengan aturan dan protap yang ada akan memberikan perlindungan hukum secara yuridis terhadap petugas pemasyarakatan tersebut. Dimana aturan-aturan hukum yang ada akan menjadi tameng hukum bagi petugas pemasyarakatan dalam melindungi dirinya terhadap segala tuntutan yang akan muncul terkait ekses yang timbul akibat tugas pengamanan yang dijalankan. ${ }^{8}$

Pernyataan yang disampaikan oleh Kepala Lapas Klas IIA Padang tersebut dalam pandangan teori hukum dapat dimaknai sebagai perlindungan hukum secara normative, dimana perlindungan hukum diberikan berdasar norma-norma hokum yang ada. Hal ini dapat dipahami dari pemaknaan perlindungan hukum dari Satjipto Rahardjo yang melihat bahwa norma-norma hukum tidak hanya dipandang sebagai rangkaian kata tertulis tapi juga harus dapat dimaknai sebagai betuk dasar pelaksanaan

${ }^{8}$ Wawancara dengan Sri Yuwono, Ka Lapas Klas IIA Padang, tanggal 12 Februari 2018 perlindungan hukum terhadap setiap subjek hokum. ${ }^{9}$

KendalaDalam Pelaksanaan Perlindungan Hukum Terhadap Petugas Pemasyaraktan Dalam Pelaksanaan Tugas Pengamanan Di Lapas Klas IIA Padang.

Perlindungan hukum terhadap Petugas Pemasyarakatan di Lapas Klas IIA memiliki beberapa kendala dalam pelaksanaanya. Kendala-kendala tersebut dapat dikelompokkan atas empat kendala utama yakni : kendala yuridis, kendala struktural, kendala operasional dan kendala personal.Kendala yuridis dalam pelaksanaan perlindungan hukum terhadap petugas pemasyarakatan di Lapas Klas IIA Padang meliputi beberapa hal yaitu :

1. Belum adanya aturan khusus yang memberikan hak deskresi terhadap petugas pemasyarakatan dalam menjalankan tugas pengamanan yang memberikan kewenangan untuk mengambil tindakan dalam keadaaan tertentu khusunya dalam mengantasipasi keadaan chaos atau keadaan overmacht dalam kondisi-kondisi keamanan darurat.

2. Belum adanya aturan yang memberikan uraian kewenangan secara spesifik tentang kewenangan yang dimiliki oleh petugas pengamanan dalam melaksanakan tugas pengamanan di Lembaga Pemasyarakatan.

3. Belum adanya peraturan pelaksanan lebih lanjut sebagai Petunjuk Pelaksana (Juklak)

${ }^{9}$ Ibid 
ataupun Petunjuk Teknis (Juknis) dalam

pelaksanaan perlindungan hukum terhadap petugas Pemasyarakatan sebagaimana diatur dalam Pasal 36 dan 37

Peremenkumham No. 33 Tahun 2015.

\section{PENUTUP}

Perlindungan hukum terhadap petugas pemasyarakatan di Lapas Klas IIA Padang dilaksanakan berdasarkan ketentuanketentuan hokum tentang pemasyarakatan. Dalam hal ini Lapas Klas IIA Padang memberikan perlindungan hokum kepada petugas pemasyarakatan dalam melaksanakan tugas pengamanan yang dijalankan sesuai aturan-aturan hokum yang berlaku tentang tugas pemasyarakatan dan aturan hokum tentang pengamanan itu sendiri. Aturan hokum implementatif tentang pemasyarakatan tentang pengamanan tersebut merujuk pada aturan hokum tentang kode etik pemasyarakatan dan aturan hokum tentang pengamanan Lapas yang diatur dalam Permenkumham Nomor M.HH16.KP.05.02 Tahun 2011 Tentang Kode Etik Pegawai Pemasyarakatan dan Permenkumham No. 33 Tahun 2015 Tentang Pengamanan Pada Lembaga Pemasyarakatan dan Rumah Tahanan Negara. Pelaksanaan perlindungan hokum terhadap petugas pemasyarakatan dalam menjalankan tugas pengamanan dijalankan berdasarkan aturan hokum tersebut, sehingga perlindungan hokum terhadap petugas pemasyarakatan dapat diberikan dalam hal petugas pemasyarakatan menjalankan tugas pengamanan berdasarkan aturan-aturan hokum yang berlaku.

Kendala kendala yang ditemui dalam pelaksanaan Perlindungan hokum terhadap petuga Lembaga Pemasyarakatan dalam Pelaksanaankan tugas Pengamanan di Lembaga Pemasyarakatan Klas IIA Padang minimnya SDM dan sarana prasarana Pengaman,minimnya Anggaran, terbatasnya tenaga pengamanan, serta padatnya Pengunjung dan arus barang yang keluar masuk yang bersamaan di Lapas Klas IIA Padang mengakibatkan kurang cermatnya pemeriksaan karena masih bersifat manual.

\section{DAFTAR PUSTAKA}

\section{Buku-Buku}

Didin Sudirman, Reposisi dan Revitalisasi Pemasyarakatan dalam Sistem Peradilan Pidana di Indonesia, Pusat Pengkajian dan Pengembangan Kebijakan Departemen Hukum dan Hak Asasi Manusia RI, Jakarta, 2007.

Irjen Pol. (Purn) Prof. Dr. Farouk Muhammad, Pemahaman Tentang Konsep Keamanan.

Muhari Agus Santoso, Paradigma Baru Hukum Pidana, Averroes Press \& Pustaka Pelajar, Malang, 2004.

Samsul Hidayat, Modul Pengamanan Pada Lapas dan Rutan, Pusat Pengembangan Teknis dan Kepemimpinan Badan Pengembangan Sumber Daya Manusia Hukum dan HAM, Jakarta. 2017. 


\section{Peraturan Undang-Undang}

Peraturan Menteri Hukum dan Hak Asasi Manusia Nomor 33 Tahun 2015 tentang Pengamanan pada Lembaga Pemasyarakatan dan Rumah Tahanan Negara

Undang-Undang Nomor 12 Tahun 1995 tentang Pemasyarakatan 